\title{
Thickness changes on Whillans Ice Stream and Ice Stream C, West Antarctica, derived from laser altimeter measurements
}

\author{
Vandy Blue SPIKeS, ${ }^{1,2}$ BeÁta M. CSATHÓ, ${ }^{1}$ Gordon S. HAMILTON, ${ }^{2}$ Ian M. WHILlanS ${ }^{1 \dagger}$ \\ ${ }^{1}$ Byrd Polar Research Center, The Ohio State University, 1090 Carmack Road, Columbus, Ohio 43210-1002, U.S.A. \\ E-mail:vandy.spikes@maine.edu \\ ${ }^{2}$ Department of Geological Sciences and Institute for Quaternary and Climate Studies, University of Maine, Orono, Maine 04469-5790, U.S.A.
}

\begin{abstract}
Repeat airborne laser altimeter measurements are used to derive surface elevation changes on parts of Whillans Ice Stream and Ice Stream C, West Antarctica. Elevation changes are converted to estimates of ice equivalent thickness change using local accumulation rates, surface snow densities and vertical bedrock motions. The surveyed portions of two major tributaries of Whillans Ice Stream are found to be thinning almost uniformly at an average rate of $\sim 1 \mathrm{~m} \mathrm{a}^{-1}$. Ice Stream $\mathrm{C}$ has a complicated elevation-change pattern, but is generally thickening. These results are used to estimate the contribution of each surveyed region to the current rate of global sea-level rise.
\end{abstract}

\section{INTRODUGTION}

Thinning of the West Antarctic ice sheet (WAIS) may account for a portion of the current rate of global sea-level rise (Church and others, 2001). The primary drainage features of the WAIS, the Ross ice streams, are undergoing substantial changes in length, width, thickness and speed at decadal and shorter time-scales (Bindschadler and Vornberger, 1998; Hamilton and others, 1998; Echelmeyer and Harrison, 1999; Joughin and others, 1999; Price and Whillans, 2001; Whillans and others, 2001; Joughin and Tulaczyk, 2002). Ice from the interior of the WAIS is funneled through the Ross ice streams on its way to the ocean, so changes occurring in the ice streams may reflect broader-scale and longer-term changes of the entire ice sheet. Understanding the changes that are occurring throughout the Ross ice-stream system is therefore critical for determining the mass balance of the WAIS and its effect on global sea level.

While understanding of the mechanics of ice-stream flow has improved greatly over the last two decades, direct measurements of the changes occurring in these regions are restricted to a few isolated field sites. Airborne geophysical programs are capable of covering larger regions than is possible with ground-based programs. The U.S. National Science Foundation's (NSF) Support Office for Aerogeophysical Research (SOAR) operated a geophysically outfitted aircraft in Antarctica during the 1990s. The procedure used to collect, calculate, calibrate and validate SOAR laser altimeter measurements is described by Spikes and others (2003). This companion paper presents and interprets elevation changes measured using the SOAR system over ice streams in West Antarctica.

\footnotetext{
$\dagger$ Deceased 9 May 2001.
}

\section{STUDY AREA}

This study focuses on Ice Stream C (ISG) and the two tributaries to Whillans Ice Stream (WIS), Whillans-1 and Whillans2 (W1 and W2) (Fig. 1). Water and till beneath the ice streams lubricate the contact between ice and substrate, whereas the interstream ridges are likely frozen to the bed (Alley and others, 1986, 1987; Blankenship and others, 1986, 1987; Engelhardt and others, 1990; Engelhardt and Kamb, 1991, 1997; Tulaczyk and others, 2000). The fast-moving (up to $\left.800 \mathrm{~m} \mathrm{a}^{-1}\right)$ ice stream is separated from the slow-moving $\left(\sim 2 \mathrm{~m} \mathrm{a}^{-1}\right)$ ridge by a narrow $(\sim 2 \mathrm{~km})$ wide zone, within which lateral shear stresses are large $(>200 \mathrm{kPa}$; Jackson and Kamb, 1997). On an active ice stream like WIS, these large shear stresses provide the primary resistance to flow (Echelmeyer and others, 1994; Raymond, 1996; Van der Veen and Whillans, 1996; Jackson and Kamb, 1997; Whillans and Van der Veen, 1997). The two regions of WIS surveyed here have different flow regimes: the region surveyed on $\mathrm{W} 1$ is fast-moving (speeds of $100-300 \mathrm{~m} \mathrm{a}^{-1}$ ), while the region surveyed on W2 is nearer to the ice-stream onset and slowermoving (speeds $<100 \mathrm{~m} \mathrm{a}^{-1}$ ). ISC is unusual because it no longer flows at rapid velocities in the downstream region despite what appears to be adequate lubrication (Retzlaff and Bentley, 1993; Whillans and Van der Veen, 1993; Bentley and others, 1998; Joughin and others, 1999).

\section{ELEVATION GHANGES}

\subsection{At crossover points}

The purpose of repeat laser profiling is to measure changes in elevation with time. Elevation changes at crossover points (Figs 2-4) and their associated errors (Spikes and others, 2003) are presented in Table 1. Several of the crossover points shown in Figures 2-4 were not surveyed in both seasons and are thus omitted from Table 1. The distance between 1997/98 and 1999/2000 crossover points, d, varies between 6 and 


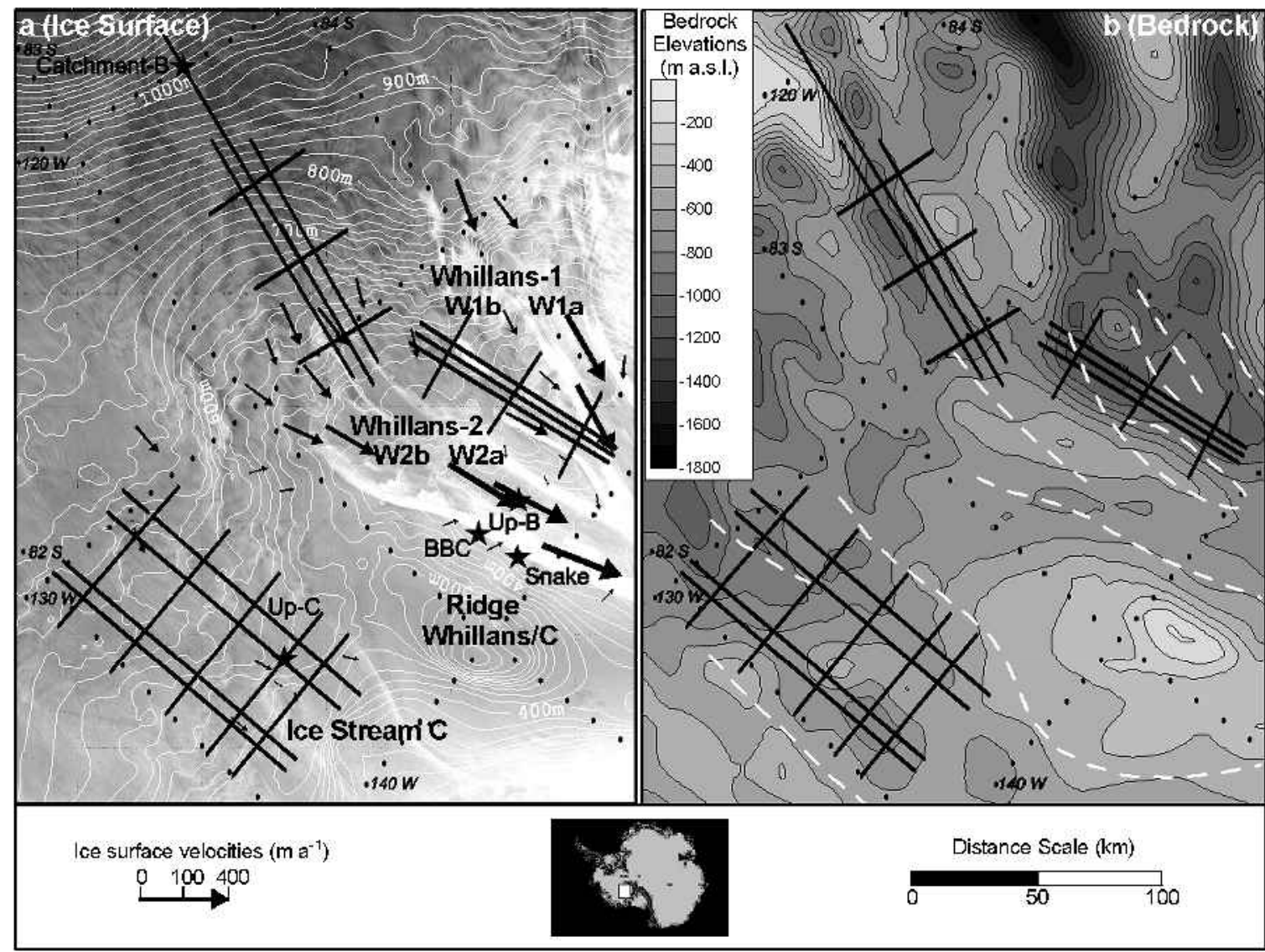

Fig. 1. (a) Laser altimetry surveys in West Antarctica (black) superimposed on a mosaic of RADARSAT images (Jezek and others, 2002). Stars represent submergence velocity stations ( see text). Ice-stream margins (dashed white lines) and ice velocity vectors are from Whillans and Van der Veen (1993). (b) Laser surveys superimposed on a contoured version of BEDMAP (Lythe and others, 2000).

$48 \mathrm{~m}$ (Table 1). Because the two seasons' crossover points are not coincident, a correction, $\mathbf{C}_{\mathbf{k}}$, is applied to remove the effects of surface slope, $\mathbf{k}$, between the points. To determine the surface slope, data within $200 \mathrm{~m}$ of the 1999/2000 crossover points are gridded and contoured (as shown in Spikes and others, 2003, fig. 9). The slope correction, $\mathbf{C}_{\mathbf{k}}=\mathbf{k} \cdot \mathbf{d}$, is then added to the elevation of the $1997 / 98$ crossover point. This corrected value is then subtracted from the elevation of the 1999/2000 crossover point to give the elevation change. Dividing the elevation change by the elapsed time between surveys gives the rate of elevation change. The errors in the rate of elevation change are related to the standard deviation of the reported $\mathrm{rms}$ for each crossover measurement.

Determination of elevation changes at crossover locations is advantageous, because the errors in the laser measurements are well understood at these locations (Spikes and others, 2003). Errors in elevation changes at crossover points range from 0.02 to $0.15 \mathrm{~m} \mathrm{a}^{-1}$ (Table 1). In most cases, the measured elevation change is much greater than the associated error. Exceptions include the two crossover points on ISC (Nos. 8 and 18) where the error was larger than the near-zero rate of elevation change (Table 1).

\subsection{Along survey lines}

Spatially continuous measurements of elevation change are obtained by comparing nearly coincident, parallel survey lines from different seasons (Figs 2-4). Elevation changes along an entire survey line are determined by subtracting each 1997/98
Table 1. Observed changes in surface elevation and calculated ice equivalent thickness changes at crossover points

\begin{tabular}{|c|c|c|c|c|}
\hline $\begin{array}{l}\text { Crossover } \\
\text { No. }\end{array}$ & $\begin{array}{c}\text { Distance between } \\
\text { crosses, } \mathbf{d} \\
\mathrm{m}\end{array}$ & $\begin{array}{c}\text { Slope } \\
\text { correction, } \mathbf{C}_{\mathbf{k}} \\
\mathrm{m}\end{array}$ & $\begin{array}{c}\text { Elevation } \\
\text { change } \\
\mathrm{m} \mathrm{a}^{-1}\end{array}$ & $\begin{array}{c}\text { Thickness } \\
\text { change } \\
\mathrm{ma}^{-1}\end{array}$ \\
\hline \multicolumn{5}{|l|}{ W1 } \\
\hline 1 & 36.84 & -0.15 & $-0.95 \pm 0.09$ & $-0.91 \pm 0.09$ \\
\hline 2 & 21.174 & -0.05 & $-0.62 \pm 0.05$ & $-0.58 \pm 0.06$ \\
\hline 3 & 12.11 & 0.06 & $-0.49 \pm .003$ & $-0.45 \pm .03$ \\
\hline 4 & 11.32 & 0.05 & $-0.67 \pm 0.05$ & $-0.63 \pm 0.06$ \\
\hline 5 & 21.83 & -0.1 & $-0.83 \pm 0.02$ & $-0.79 \pm 0.03$ \\
\hline 6 & 26.6 & 0.08 & $-0.47 \pm 0.07$ & $-0.43 \pm 0.08$ \\
\hline 7 & 27.84 & -0.15 & $-0.42 \pm 0.04$ & $-0.38 \pm 0.05$ \\
\hline 8 & 6.39 & -0.03 & $-0.61 \pm 0.02$ & $-0.57 \pm 0.03$ \\
\hline 9 & 27.73 & 0.03 & $-0.47 \pm 0.03$ & $-0.43 \pm 0.04$ \\
\hline \multicolumn{5}{|l|}{ W2 } \\
\hline 2 & 47.03 & 0.2 & $-0.73 \pm 0.13$ & $-0.69 \pm 0.13$ \\
\hline 3 & 47.163 & -0.21 & $-0.64 \pm 0.07$ & $-0.60 \pm 0.08$ \\
\hline 5 & 47.943 & 0.22 & $-0.43 \pm 0.1$ & $-0.39 \pm 0.1$ \\
\hline 6 & 19.87 & -0.07 & $-0.59 \pm 0.08$ & $-0.55 \pm 0.08$ \\
\hline 8 & 46.44 & 0.22 & $-0.53 \pm 0.15$ & $-0.49 \pm 0.15$ \\
\hline 9 & 32.39 & -0.04 & $-0.73 \pm 0.07$ & $-0.69 \pm 0.08$ \\
\hline \multicolumn{5}{|l|}{ ISC } \\
\hline 1 & 27.18 & 0.12 & $0.18 \pm 0.1$ & $0.22 \pm 0.1$ \\
\hline 3 & 18.36 & 0.02 & $0.08 \pm 0.04$ & $0.12 \pm 0.05$ \\
\hline 6 & 19.92 & -0.004 & $0.09 \pm 0.06$ & $0.13 \pm 0.07$ \\
\hline 8 & 39.16 & 0.07 & $0.01 \pm 0.07$ & $0.05 \pm 0.08$ \\
\hline 16 & 27.61 & 0.02 & $0.34 \pm 0.05$ & $0.38 \pm 0.06$ \\
\hline 18 & 35.45 & -0.08 & $-0.01 \pm 0.06$ & $0.03 \pm 0.07$ \\
\hline
\end{tabular}



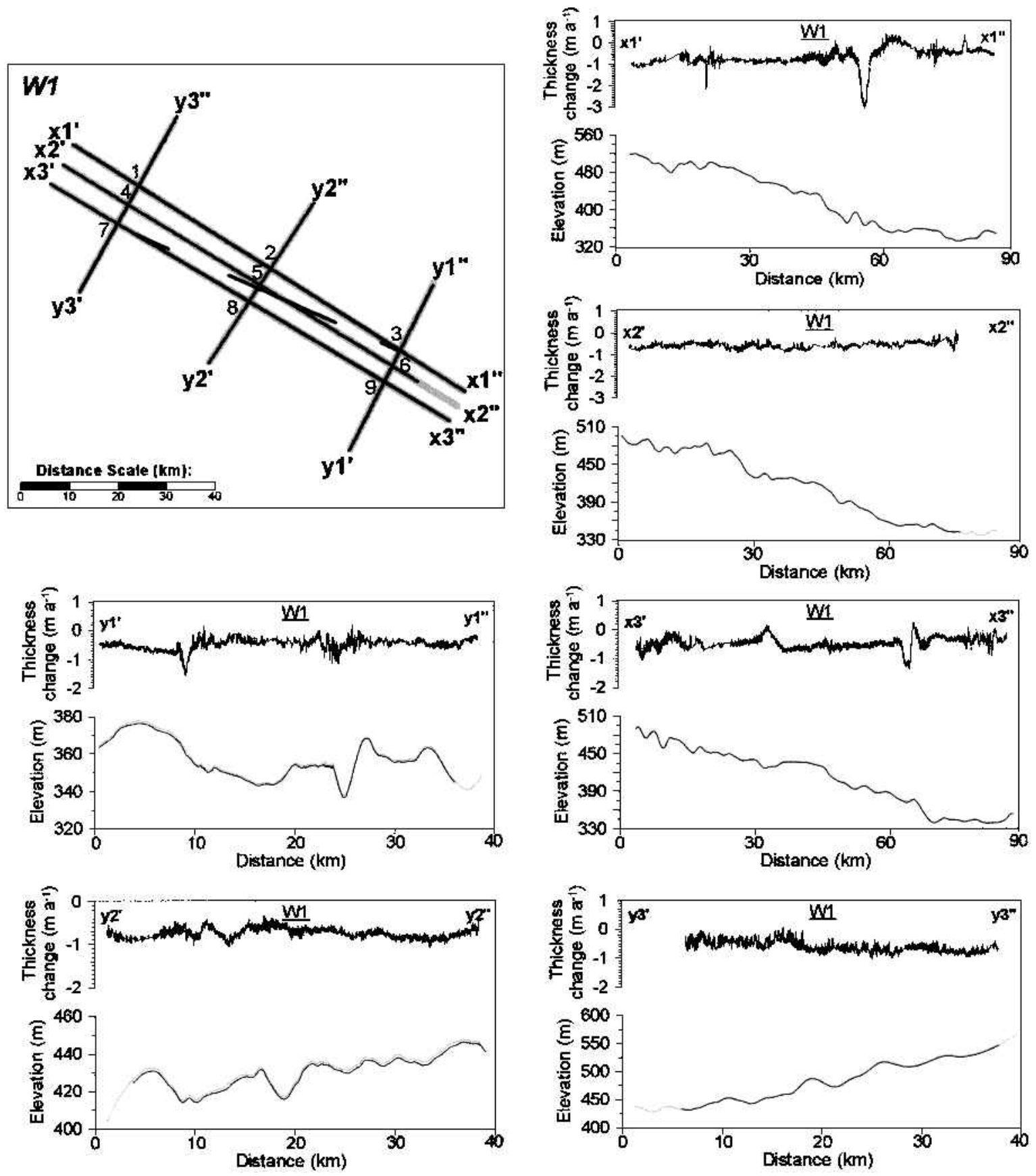

Fig. 2. Map of 1997/98 ( gray) and 1999/2000 (black) laser altimeter surveys over W1. Bold characters represent profile names (e.g. $\mathbf{x 1}^{\prime}-\mathbf{x} \mathbf{1}^{\prime \prime}$ ). Laser-derived elevations (1997/98: gray; 1999/2000: black) and calculated thickness changes are plotted for each profile.

elevation from the two or three closest 1999/2000 laser-derived elevations. The average elevation difference is then computed to remove the effects of sastrugi. The distance between the center points of the two laser measurements being compared never exceeds $40 \mathrm{~m}$, and is often $<10 \mathrm{~m}$.

Errors associated with along-track elevation changes are expected to be similar to those found at crossover points. However, no correction is used here for slope-induced errors, which could be on the order of $20 \mathrm{~cm}$ when measurements are up to $40 \mathrm{~m}$ apart (Table 1). This correction is avoided because the shape of the ice surface changes in an irregular manner across each ice stream and the orientation of each 1997/98 measurement relative to the 1999/2000 measurement also changes. Slope-induced errors likely appear in the along-track ice equivalent thickness changes (discussed below) shown in Figures 2-4, but due to the random nature of ice surface slopes and measurement orientations, it is likely that these errors cancel out while interpolating (using $1 \mathrm{~km}$ grid spacing) the ice equivalent thickness changes shown in Figure 5.

\section{ICE EQUIVALENT THICKNESS GHANGE}

\subsection{Calculating thickness change}

In order to calculate a change in mass for each surveyed region, the measured elevation changes are first converted to ice equivalent thickness changes (Table 1; Figs 2-4). Icesheet surface elevations change according to several processes: ice-velocity changes; spatial and temporal variations in the rate of snowfall and firn densification; and vertical bedrock motions. The rate of ice equivalent thickness 

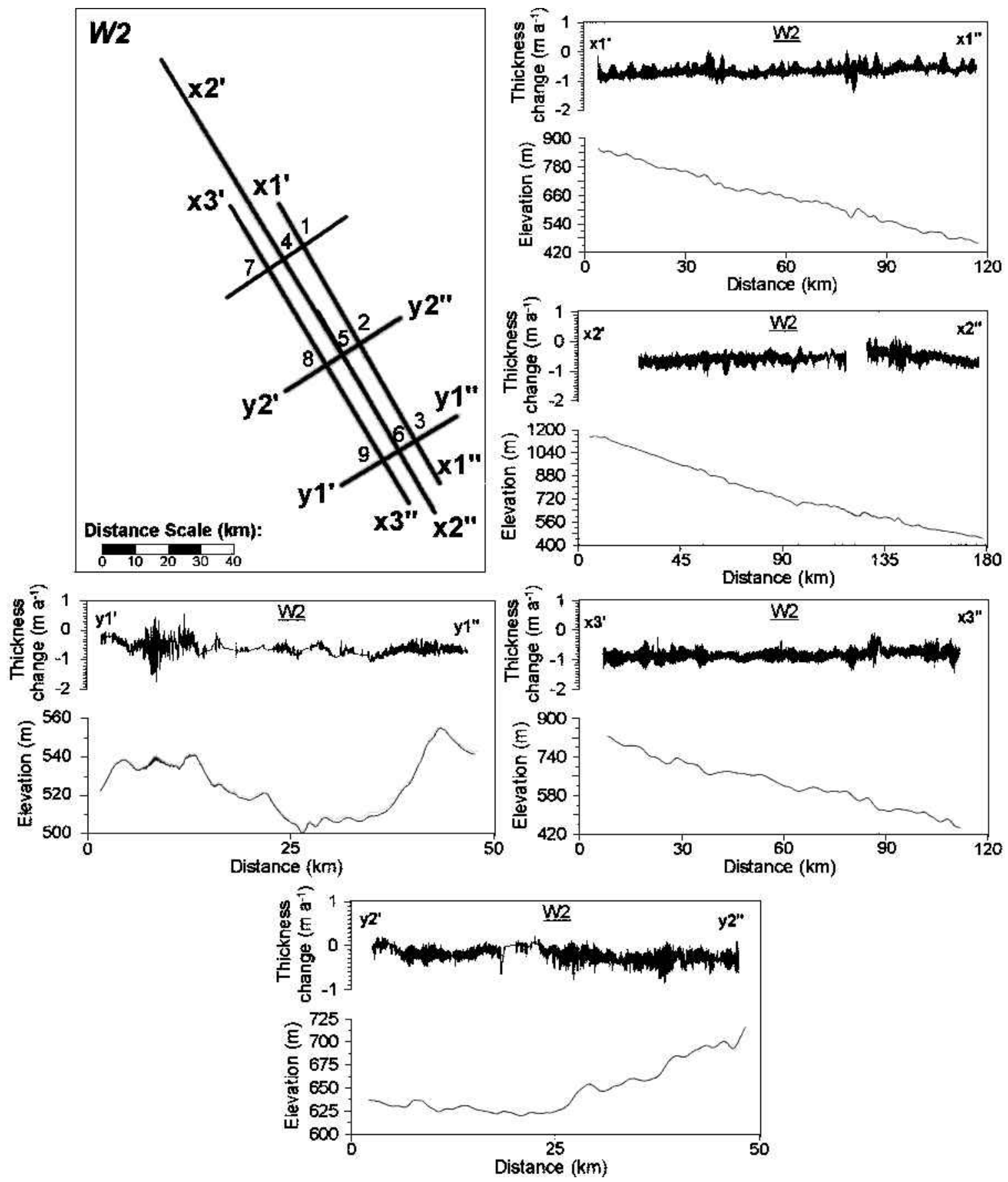

Fig. 3. Same as Figure 2, but for W2.

change, $\dot{H}$, is calculated using short-term laser measurements of ice-sheet elevation change, $\dot{z}$, according to:

$$
\dot{H}=\dot{z}-\frac{\Delta \dot{b}_{\mathrm{m}}}{\rho_{\mathrm{s}}}-u
$$

The accumulation rate, density of surface snow, and vertical motion of the subglacial bedrock are expressed as $\dot{b}_{\mathrm{m}}$ (mass per unit area and time), $\rho_{\mathrm{s}}$ (mass per unit volume) and $u$ $\left(\mathrm{m} \mathrm{a}^{-1}\right.$, positive upwards), respectively. Variations in the rate of firn densification likely contribute sub-centimeter errors to measured surface elevation changes (Wingham, 2000). This correction would have a negligible effect on the present results, and because no data are available to estimate this contribution, it is ignored. Thickness changes calculated using Equation (1) are presented in Figures 2-4 (alongtrack) and Figure 5 (gridded).

\subsection{Accounting for changes in snowfall}

Temporal variations in snow accumulation rate can introduce large errors to $\dot{H}$ (Van der Veen, 1993; Van der Veen and Bolzan, 1999; Cuffey, 2001). To remove the effects of short-term variability in snowfall, shallow cores $(<20 \mathrm{~m})$ were collected at two sites (BBC and Snake) close to the northern shear margin of W2 (Fig. 1). These cores were used to derive snow-accumulation rates based on the detection of elevated gross beta radioactivity (Whillans and Bindschadler, 1988). Using the BBC and Snake cores, the average accumulation rate for the 42 year period (1955-97) is found to be $0.082 \pm 0.014 \mathrm{Mg} \mathrm{m}^{-2} \mathrm{a}^{-1}$. The average density of the upper $20 \mathrm{~cm}$ of these two cores is $0.37 \pm 0.04 \mathrm{Mg} \mathrm{m}^{-3}$, which is used as the value for $\rho_{\mathrm{s}}$. In addition, steel poles installed at each site to measure ice velocities are used to derive short-term accumulation rates based on pole burial. BBC was installed 

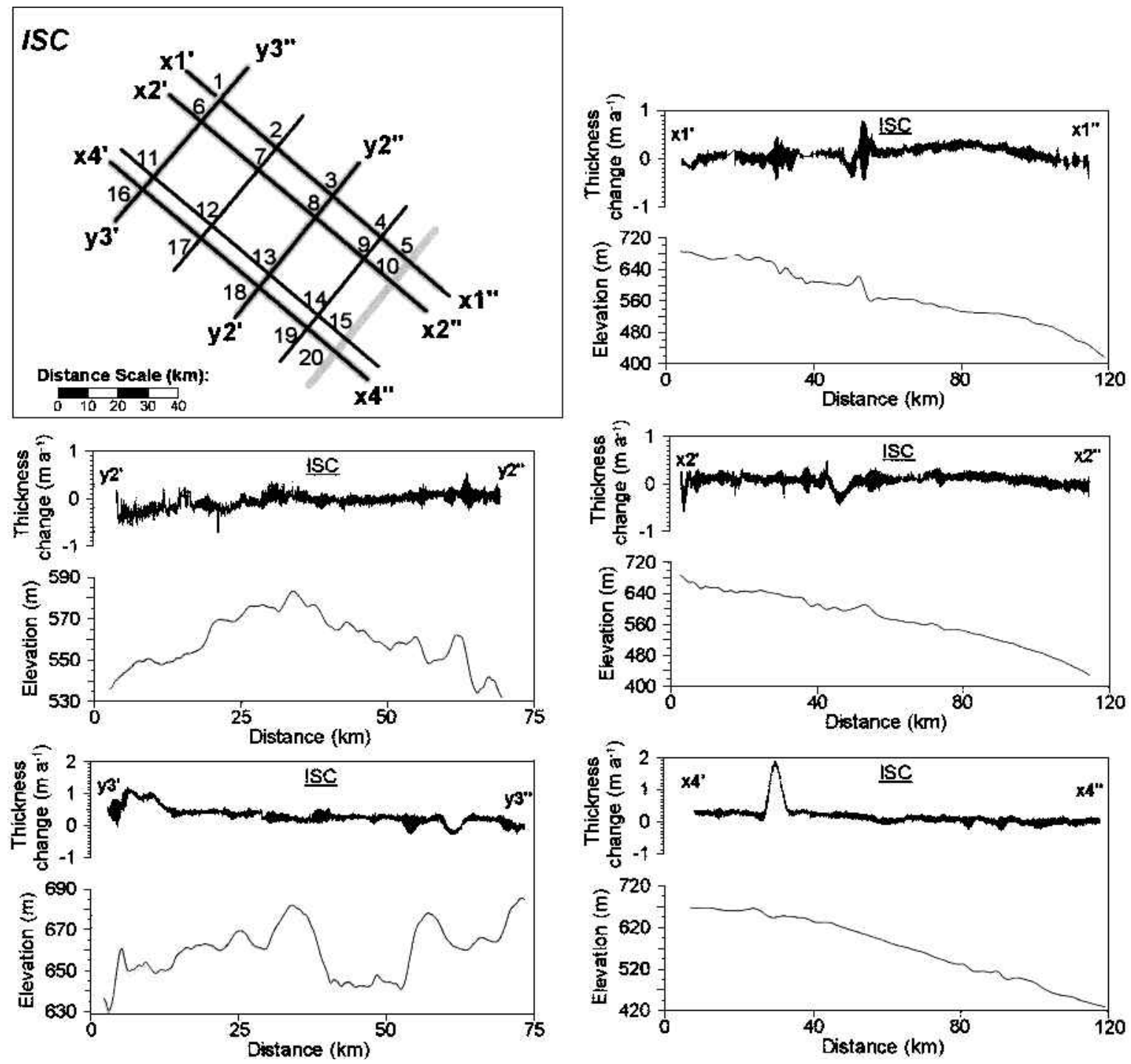

Fig. 4. Same as Figure 2, but for ISC.

in November 1996 and resurveyed in the following three seasons. Snake was installed in December 1998 and resurveyed in the following season. These measurement periods coincide with the airborne laser profiling.

The change in accumulation rate, $\Delta \dot{b_{\mathrm{m}}}$, is determined by subtracting long-term $\dot{b}_{\mathrm{m}}$, based on core stratigraphy, from the short-term accumulation rate based on pole burial. The shortterm accumulation rate is the density of surface snow multiplied by the amount of new snowfall. Using data from the two field sites over a 2 year period, an average $\Delta \dot{b}_{\mathrm{m}}$ of $-0.019 \pm$ $0.02 \mathrm{Mg} \mathrm{m}^{-2} \mathrm{a}^{-1}$ is obtained (Table 2), which is in the range of the average interannual variability of $0.018 \mathrm{Mg} \mathrm{m}^{-2} \mathrm{a}^{-1}$ found by Venteris and Whillans (1998) for the Ross ice-stream region. This mass-equivalent change in the amount of snowfall results in a $-0.05 \mathrm{~m} \mathrm{a}^{-1}$ elevation change assuming surface snow has a density of $0.37 \mathrm{Mg} \mathrm{m}^{-3}$. It is important to note that the measured increase in $\dot{b}_{\mathrm{m}}$ represents variability over a 2 year period, and most likely does not represent a longer-term change.

\subsection{Accounting for isostasy}

Isostatic adjustment due to glacial loading or unloading also contributes to measured elevation changes of the ice-sheet surface. The term $u$ in Equation (1) is the sum of the short-

term elastic changes in bedrock elevations and the longerterm viscoelastic changes. The best estimate of present-day glacial rebound comes from James and Ivins (1998) who predict that $u=0.008 \mathrm{~m} \mathrm{a}^{-1}$ for the areas included in this study. Relative to the calculated values of $\dot{H}$ and the associated errors (see below), $u$ is negligible. Nevertheless, it is included here for completeness.

\subsection{Error budget}

To estimate the standard error of $\dot{H}$, uncertainties in the quantities in Equation (1) are combined using the law of propagation of variances, so that:

$$
\sigma_{\dot{H}}^{2}=\rho_{\mathrm{s}}^{-2} \sigma_{\Delta \dot{b}_{\mathrm{m}}}^{2}+\Delta \dot{b}_{\mathrm{m}}^{2} \rho_{\mathrm{s}}^{-4} \sigma_{\rho_{\mathrm{s}}}^{2}+\sigma_{\dot{z}}^{2}+\sigma_{u}^{2} .
$$

The uncertainty in measured elevation changes, $\sigma_{\dot{z}}=0.08 \mathrm{~m}$ $\mathrm{a}^{-1}$, is the standard deviation of the errors at crossover points in Table 1. The error associated with James and Ivins' (1998) predicted rate of glacial rebound is $\sigma_{u}=0.002 \mathrm{~m} \mathrm{a}^{-1}$. The change in accumulation rate has an associated error of $\sigma_{\Delta \dot{b_{\mathrm{m}}}}=$ $0.01 \mathrm{Mg} \mathrm{m}^{-2} \mathrm{a}^{-1}$ (Table 2). The error in the density of surface snow at BBC and Snake is $\sigma_{\rho_{\mathrm{s}}}=0.04 \mathrm{Mg} \mathrm{m}^{-3}$. The standard error $\sigma_{\dot{H}}$ for all thickness-change values is $\pm 0.08 \mathrm{~m} \mathrm{a}^{-1}$. 


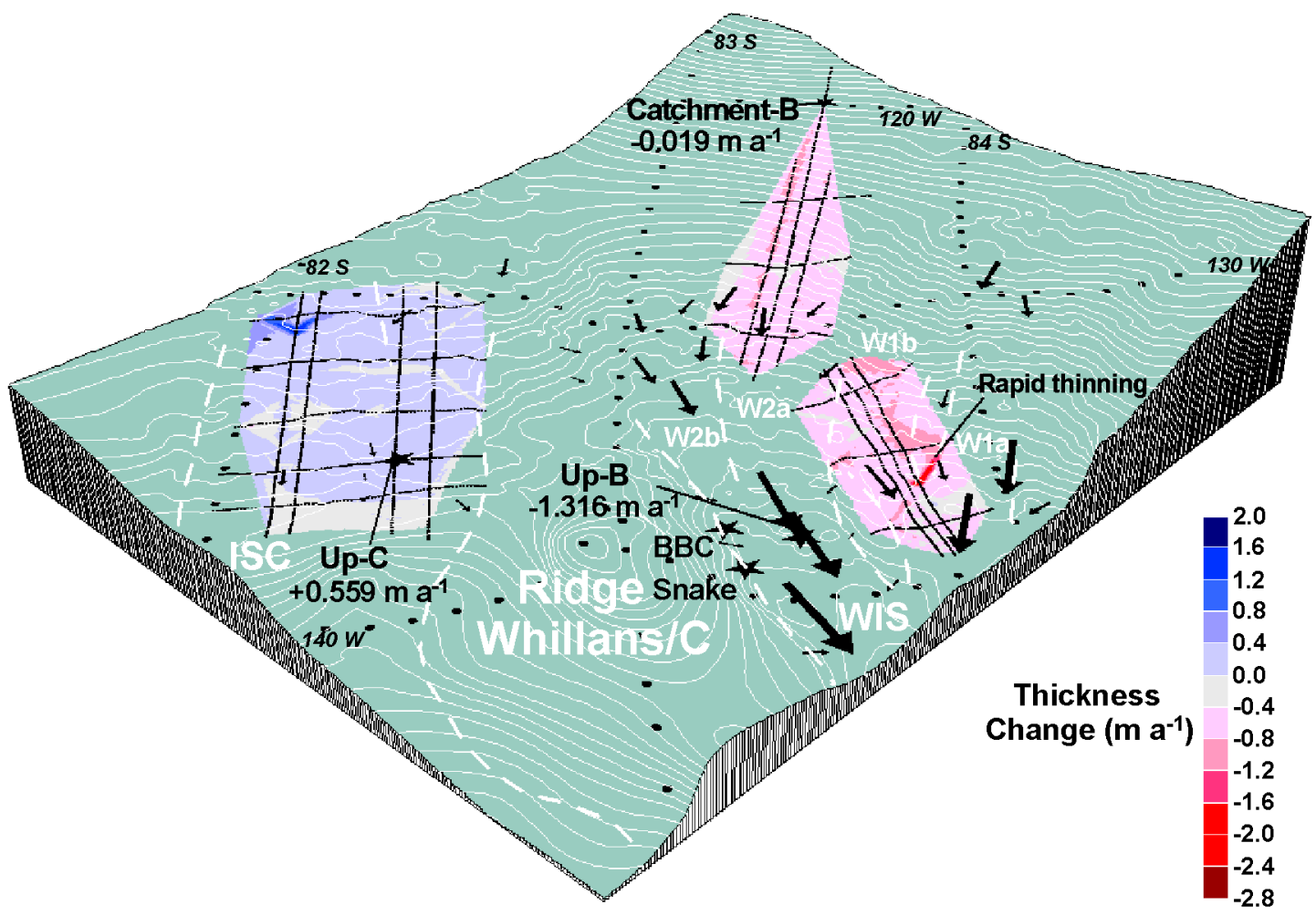

Fig. 5. Calculated rates of ice equivalent thickness change for ice streams W1, W2 and ISC (colored regions) superimposed on a three-dimensional version of the RADARSAT-1 Antarctic Mapping Project (RAMP) digital elevation model (DEM) (Liu and others, 2000). Stars represent submergence velocity stations.

\subsection{Results}

Point measurements of $\dot{H}$ obtained using the submergence velocity technique (G. S. Hamilton and I. M. Whillans, unpublished information) reveal a thinning rate of $1.316 \pm$ $0.085 \mathrm{~m} \mathrm{a}^{-1}$ for Up-B on WIS. Laser surveys over nearby W1 indicate that the ice is thinning at rates of $0.0-2.8 \mathrm{ma}^{-1}$ (average thinning $=0.57 \mathrm{~m} \mathrm{a}^{-1}$; Fig. 5). Hamilton and Whillans found no significant change in $\dot{H}$ at their Catchment-B site $\left(0.019 \pm 0.021 \mathrm{~m} \mathrm{a}^{-1}\right)$ located in the upper part of $\mathrm{W} 2$. Farther downstream laser measurements reveal that W2 is thinning at rates of $0.0-1.2 \mathrm{ma}^{-1}$ (average thinning = $0.64 \mathrm{~m} \mathrm{a}^{-1}$; Fig. 5). Ice near the Up-C submergent velocity site on ISC is thickening at a rate of $0.559 \pm 0.019 \mathrm{~m} \mathrm{a}^{-1}$ (G. S. Hamilton and I. M. Whillans, unpublished information), while laser measurements indicate that ISC is changing thickness at rates of -0.6 to $2.0 \mathrm{~m} \mathrm{a}^{-1}$ (average thickening $=0.12 \mathrm{~m} \mathrm{a}^{-1}$; Fig. 5). It should be noted that the submergence velocity results are point measurements that apply to sites that are close to $(>1 \mathrm{~km})$, but not directly cov-

Table 2. Changes in accumulation rate at submergent velocity sites BBC and Snake

\begin{tabular}{lcccc}
\hline $\begin{array}{l}\text { Site (years } \\
\text { represented) }\end{array}$ & $\begin{array}{c}\text { Accumulation } \\
\text { rate }\end{array}$ & $\begin{array}{c}\text { Density of } \\
\text { surface snow }\end{array}$ & $\begin{array}{c}\text { Amount of } \\
\text { new snowfall }\end{array}$ & $\begin{array}{c}\text { Change in } \\
\text { accumulation }\end{array}$ \\
& $\mathrm{Mg} \mathrm{m}^{-2} \mathrm{a}^{-1}$ & $\mathrm{Mg} \mathrm{m}^{-3}$ & $\mathrm{~m} \mathrm{a}^{-1}, \mathrm{Mg} \mathrm{m}^{-2} \mathrm{a}^{-1} \mathrm{Mg} \mathrm{m}^{-2} \mathrm{a}^{-1}$ \\
\hline BBC (1997/98) & 0.079 & 0.39 & $0.24,0.094$ & 0.015 \\
BBC (1998/99) & & & $0.08,0.031$ & -0.048 \\
Snake (1998/99) & 0.084 & 0.35 & $0.11,0.039$ & -0.045 \\
Avg. (1997-99) & $0.082 \pm 0.015$ & $0.37 \pm 0.04$ & $0.17 \pm 0.04$, & $0.019 \pm 0.02$ \\
& & & $0.063 \pm 0.015$ & \\
\end{tabular}

ered by, laser measurements. Therefore, a direct comparison between the two measurement techniques is not possible.

Using a continuity calculation based largely on satellite data, Joughin and others (1999) produced a map of thickness change for nearly the same area of ISC as the laser surveys presented here. They report a variable spatial pattern of thickness change ranging from 0.0 to $0.7 \mathrm{~m} \mathrm{a}^{-1}$ with an average thickening rate of $0.49 \mathrm{~m} \mathrm{a}^{-1}$. The range of thicknesschange rates found by Joughin and others (1999) are significantly less than the range found with laser altimetry, which results in the higher average thickening rate found with the continuity calculation. Given the relatively large uncertainties associated with the ice velocities and ice thicknesses used for the continuity calculation, it is expected that the direct laser measurements yield the more accurate thickness-change results.

\section{DISGUSSION}

Thickening in the upper regions of ISC is most likely due to the stagnation of the lower part of the ice stream. Ice thickness decreases by a factor of two from the upstream part of the laser grid to the downstream part, mostly as a result of increased bed elevations. Velocities decrease from 25 to $3 \mathrm{~m} \mathrm{a}^{-1}$ for the same region, and surface slope increases by a factor of 2. As more ice moves into the region, ice thicknesses should increase as a result of compression (Whillans and Van der Veen, 1993; Price and others, 2001). Laser measurements and point measurements of mass balance confirm that ISC is thickening as it approaches the downstream bedrock ridges. The growing bulge on ISC is likely an indicator that the ice stream is building towards a renewed episode of rapid flow. 
Several studies have shown that parts of WIS are changing over time, notwithstanding the results of the Joughin and Tulaczyk (2002) study, which suggest that overall this ice stream is in balance. This ice stream is known to be decelerating, although it is still active all the way to the Ross Ice Shelf (Whillans and others, 2001; Joughin and Tulaczyk, 2002). Price and Whillans (2001) studied the pattern of marginal crevasses near the head of the Wlb tributary and concluded that the onset to streaming flow was migrating upstream. In addition, ice from a nearby ISC tributary is being diverted to W2 (Price and others, 2001) due to increased surface slopes across the WIS/ISC ridge that are the result of long-term thinning of WIS and thickening of ISC. Other studies have revealed that ice is also entering WIS through the lateral margins, which are migrating toward the interstream ridges at rates on the order of tens of meters per year (Hamilton and others, 1998; Echelmeyer and Harrison, 1999). Rapid thinning, widening and a $23 \%$ reduction in ice velocities show that this ice stream is responding to many changes all at once. Given the nature of these observations, it is unlikely that the current behavior of WIS can be sustained. One end-member scenario is that this ice stream may be approaching stagnation (Alley, 2002; Joughin and Tulaczyk, 2002).

Spatial variability in the rate of thickness change occurs on WIS and ISC (Figs 2-5). Possible explanations for the variability include: (1) spatial variability in $\Delta \dot{b_{m}}$; (2) kinematic waves traveling downstream; (3) downstream advection of ice with different characteristics (e.g. ice entering the ice stream from the sides); and (4) dynamic changes in ice velocity related to changes in the bed. Spatial variability in accumulation does occur, but the resulting thickness changes are only expected to be on the order of centimeters. Kinematic waves or the presence of rafted ice should result in a measurable surface bump or depression, but identifying these features would require at least one more season of surveying to track the movement of elevation changes. Most of the anomalous changes in thickness appear over bedrock valleys, suggesting that a change in ice velocity has caused the ice to either build up as it reaches a bedrock ridge, or thin as it passes one. The best example of rapid thinning as a result of a change in ice velocity occurs where W1b meets Wla (Fig. 5). According to Joughin and Tulaczyk (2002), the ice speeds up by a factor of three $\left(100-300 \mathrm{~m} \mathrm{a}^{-1}\right)$ at this junction. Whatever the cause, the variability at each location must change regularly, because advancing these exact changes forward in time would quickly result in surface hills and depressions with improbable magnitudes. Future monitoring of elevations in these regions would likely reveal a different pattern of variability, and possibly would show that these variations propagate downstream with the flow of ice.

\section{CONTRIBUTIONS TO GLOBAL SEA-LEVEL GHANGE}

The current best estimate for the rate of global sea-level rise is $1.0-2.0 \mathrm{~mm} \mathrm{a}^{-1}$ (Church and others, 2001). Estimates of the contribution of the Ross ice streams (Ice Streams A, C, D, E, $\mathrm{F}$ and Whillans Ice Stream) range from $0.058 \mathrm{~mm} \mathrm{a}^{-1}$ $\left(-20.9 \pm 13.7 \mathrm{Gta}^{-1}\right.$; Shabtaie and Bentley, 1987) to $-0.074 \mathrm{~mm} \mathrm{a}^{-1}\left(26.8 \pm 14.9 \mathrm{Gt} \mathrm{a}{ }^{-1}\right.$; Joughin and Tulaczyk, 2002). Calculations of sea-level change are based on Church and others' (2001) oceanic surface area of $3.62 \times 10^{8} \mathrm{~km}^{2}$. While the current study does not have the spatial coverage
Table 3. Estimated contributions of surveyed areas to the rate of global sea-level rise

\begin{tabular}{ccccc}
\hline Ice stream & $\begin{array}{c}\text { Area } \\
\text { surveyed }\end{array}$ & $\begin{array}{c}\text { Change in } \\
\text { volume }\end{array}$ & $\begin{array}{c}\text { Change in } \\
\text { mass } \\
\mathrm{km}^{2}\end{array}$ & $\begin{array}{c}\text { Resulting sea-level } \\
\text { change }\end{array}$ \\
$\mathrm{km}^{3} \mathrm{a}^{-1}$ & $10^{12} \mathrm{~kg} \mathrm{a}^{-1}$ & $\mathrm{~mm} \mathrm{a}^{-1}$ \\
$\mathrm{~W} 1$ & 3,036 & -1.941 & -1.766 & $0.0048 \pm 0.0001$ \\
$\mathrm{~W} 2$ & 3,850 & -2.336 & -2.126 & $0.0059 \pm 0.0001$ \\
$\mathrm{ISC}$ & 7,656 & 0.896 & 0.815 & $-0.0023 \pm 0.0001$ \\
Total & 14,542 & -3.381 & -3.077 & $0.0085 \pm 0.0002$ \\
\hline
\end{tabular}

required to make a similar calculation for the entire Siple Coast catchment, we can estimate the sea-level equivalent contribution from each surveyed area (Table 3).

InTable 3, values refer to the planar areas shown in color in Figure 5. The change in volume is the cumulative ice equivalent thickness change, $\dot{H}$, for each given area. The error in the volume is the standard error of $\dot{H}$ multiplied by the area. The change in mass is the change in volume multiplied by the density of ice $\left(0.91 \mathrm{Mg} \mathrm{m}^{-3}\right)$. The mass of ice lost within the survey grids accounts for $\sim 0.0085 \mathrm{~mm} \mathrm{a}^{-1}$ of sealevel change, which is $0.43-0.85 \%$ of the current rate of global sea-level rise. This contribution is significant considering that the area surveyed represents only $0.11 \%$ of the total ice-covered area of Antarctica.

The laser-derived results appear to be inconsistent with Joughin and Tulaczyk's (2002) estimate that the entire Ross ice-stream region is presently gaining mass. It is important to note that the laser-derived results do not account for any changes that might be occurring outside of the survey grids, including catchment zones for each ice stream. As Joughin and Tulaczyk (2002) show, a thinning ice stream can be balanced by new snow accumulation throughout the entire catchment area or by thickening in an adjacent ice stream.

\section{GONGLUSIONS}

Ice-surface elevation changes measured from 1997 to 1999 using the SOAR laser altimeter system are presented for W1, W2 and ISC. The measured elevation changes are in most cases too large to be explained by a sudden change in the rate of snowfall, firn densification or bedrock motions. We interpret most of the measured elevation changes to represent non-steady-state, ice equivalent thickness change.

The results represent the first direct thickness-change measurements over large sections of the Ross ice streams. The surveyed parts of two WIS tributaries are shown to be thinning at average rates of $0.57 \mathrm{~m} \mathrm{a}^{-1}(\mathrm{Wl})$ and $0.64 \mathrm{~m} \mathrm{a}^{-1}$ (W2). The surveyed part of ISC is thickening at an average rate of $0.12 \mathrm{~m} \mathrm{a}^{-1}$. The values derived with this method agree reasonably well with results of point mass-balance measurements and calculated thickness-change estimates by Joughin and others (1999).

The contribution of each surveyed area to global sea level is also estimated. The surveyed areas account for $0.43-0.85 \%$ of the current rate of global sea-level rise, assuming the amount of ice lost is not balanced by accumulation in other regions. It is unclear whether or not this value is in agreement with Joughin and Tulaczyk's (2002) estimate that the entire Ross ice-stream region has a slightly positive mass balance. More direct measurements, such as 
those presented here, are needed to determine whether the entire Ross ice-stream region is gaining or losing mass.

\section{AGKNOWLEDGEMENTS}

We would like to thank the personnel of SOAR for data collection and support. NSF provided the funding through OPP-9615114. RAMP DEM data were provided by the Earth Observing System (EOS) Distributed Active Archive Center at the National Snow and Ice Data Center, University of Colorado, Boulder, CO. Thanks also to I. R. Joughin, S. F. Price and T. A. Scambos for thorough reviews.

\section{REFERENGES}

Alley, R. B. 2002. On thickening ice? Science, 295(5554), 451-452.

Alley, R. B., D. D. Blankenship, C. R. Bentley and S. T. Rooney. 1986. Deformation of till beneath Ice Stream B, West Antarctica. Nature, 322(6074), 57-59.

Alley, R. B., D. D. Blankenship, C. R. Bentley and S. T. Rooney. 1987. Till beneath Ice Stream B. 3. Till deformation: evidence and implications. 7. Geophys. Res., 92(B9), 8921-8929.

Bentley, C. R., N. Lord and C. Liu. 1998. Radar reflections reveal a wet bed beneath stagnant Ice Stream $\mathrm{C}$ and a frozen bed beneath ridge $\mathrm{BC}$, West Antarctica. 7. Glaciol., 44(146), 149-156.

Bindschadler, R. and P. Vornberger. 1998. Changes in the West Antarctic ice sheet since 1963 from declassified satellite photography. Science, 279(5351), 689-692.

Blankenship, D. D., C. R. Bentley, S. T. Rooney and R. B. Alley. 1986. Seismic measurements reveal a saturated porous layer beneath an active Antarctic ice stream. Nature, 322(6074), 54-57.

Blankenship, D. D., C. R. Bentley, S.T. Rooney and R. B. Alley. 1987. Till beneath Ice Stream B. 1. Properties derived from seismic travel times. 7. Geophys. Res., 92(B9), 8903-8911.

Church, J. A. and 7 others. 2001. Climate change 2001: the scientific basis. In Houghton, J.T. and 7 others, eds. The scientific basis: contribution of Working Group I to the third assessment report of the Intergovernmental Panel on Climate Change. Cambridge, Cambridge University Press. Intergovernmental Panel on Climate Change, WMO/UNEP, 359-405.

Cuffey, K. M. 2001. Interannual variability of elevation on the Greenland ice sheet: effects of firn densification, and establishment of a multi-century benchmark. 7. Glaciol., 47(158), 369-377.

Echelmeyer, K. A. and W. D. Harrison. 1999. Ongoing margin migration of Ice Stream B, Antarctica. 7. Glaciol., 45(150), 361-369.

Echelmeyer, K. A., W. D. Harrison, C. Larsen and J. E. Mitchell. 1994. The role of the margins in the dynamics of an active ice stream. F. Glaciol., 40(136), 527-538.

Engelhardt, H. and B. Kamb. 1991. Antarctic Ice Stream B: conditions controlling its motion and interactions with the climate system. International Association of Hydrological Sciences Publication 208 (Symposium at St Petersburg 1990-Glaciers-Ocean-Atmosphere Interactions), 145-154.

Engelhardt, H. and B. Kamb. 1997. Basal hydraulic system of a West Antarctic ice stream: constraints from borehole observations. F. Glaciol., 43(144), 207-230

Engelhardt, H., N. Humphrey, B. Kamb and M. Fahnestock. 1990. Physical conditions at the base of a fast moving Antarctic ice stream. Science, 248(4951), 57-59
Hamilton, G. S., I. M. Whillans and P. J. Morgan. 1998. First point measurements of ice-sheet thickness change in Antarctica. Ann. Glaciol., 27, 125-129.

Jackson, M. and B. Kamb. 1997. The marginal shear stress of Ice Stream B, West Antarctica. 7. Glaciol., 43(145), 415-426.

James, T. S. and E. R. Ivins. 1998. Predictions of Antarctic crustal motions driven by present-day ice sheet evolution and by isostatic memory of the Last Glacial Maximum. 7. Geophys. Res., 103(B3), 4993-5017.

Jezek, K. C. and RAMP Product Team. 2002. RAMPAMM-1 SAR image mosaic of Antarctica. Fairbanks, AK, Alaska SAR Facility, in association with the National Snow and Ice Data Center, Boulder, CO.

Joughin, I. and S. Tulaczyk. 2002. Positive mass balance of the Ross ice streams, West Antarctica. Science, 295(5554), 476-480.

Joughin, I. and 7 others. 1999. Tributaries of West Antarctic ice streams revealed by RADARSAT interferometry. Science, 286(5438), 283-286.

Liu, H., K.C. Jezek and B. Li. 2000. RADARSAT Antarctic Mapping Project digital elevation model. Boulder, CO, National Snow and Ice Data Center. (Data available by FTP.)

Lythe, M. B., D. G. Vaughan and BEDMAP consortium. 2000. BEDMAPbed topography of the Antarctic. (Scale 1: 10,000,000.) British Antarctic Survey. (BAS (Misc) 9, http://www.antarctica.ac.uk/aedc/bedmap/.)

Price, S. F. and I. M. Whillans. 2001. Crevasse patterns at the onset to Ice Stream B, West Antarctica. 7. Glaciol., 47(156), 29-36.

Price, S. F., R. A. Bindschadler, C. L. Hulbe and I. R. Joughin. 2001. Poststagnation behavior in the upstream regions of Ice Stream C, West Antarctica. f. Glaciol., 47(157), 283-294.

Raymond, C. 1996. Shear margins in glaciers and ice sheets. 7. Glaciol., 42(140), 90-102.

Retzlaff, R. and C. R. Bentley. 1993. Timing of stagnation of Ice Stream C, West Antarctica, from short-pulse radar studies of buried surface crevasses. $\mathcal{F}$. Glaciol., 39(133), 553-56l.

Shabtaie, S. and C.R. Bentley. 1987. West Antarctic ice streams draining into the Ross Ice Shelf: configuration and mass balance. 7. Geophys. Res., 92(B2), 1311-1336. (Erratum: 92 (B9), 1987, p. 9451.)

Spikes, V. B., B. Csathó and I. Whillans. 2003. Laser profiling over Antarctic ice streams: methods and accuracy. F. Glaciol., 49(165), 315-322.

Tulaczyk, S. M., B. Kamb and H. F. Engelhardt. 2000. Basal mechanics of Ice Stream B, West Antarctica. II. Undrained-plastic-bed model. F. Geophys. Res., 105(B1), 483-494.

Van der Veen, C. J. 1993. Interpretation of short-time ice-sheet elevation changes inferred from satellite altimetry. Climatic Change, 23(4), 383-405.

Van der Veen, C. J. and J. F. Bolzan. 1999. Interannual variability in net accumulation on the Greenland ice sheet: observations and implications for mass balance measurements. F. Geophys. Res., 104(D2), 2009-2014.

Van derVeen, C. J. and I. M. Whillans. 1996. Model experiments on the evolution and stability of ice streams. Ann. Glaciol., 23, 129-137.

Venteris, E. R. and I. M. Whillans. 1998. Variability of accumulation rate in the catchments of Ice Streams B, C, D and E, Antarctica. Ann. Glaciol., 27, 227-230.

Whillans, I. M. and R. A. Bindschadler. 1988. Mass balance of Ice Stream B, West Antarctica. Ann. Glaciol., 11, 187-193.

Whillans, I. M. and C. J. van der Veen. 1993. New and improved determinations of velocity of Ice Streams B and C, West Antarctica. 7. Glaciol., 39(133), 483-490.

Whillans, I. M. and C. J. van der Veen. 1997. The role of lateral drag in the dynamics of Ice Stream B, Antarctica. F. Glaciol., 43(144), 231-237.

Whillans, I. M., C. R. Bentley and C. J. van der Veen. 2001. Ice Streams B and C. In Alley, R. B. and R. A. Bindschadler, eds. The West Antarctic ice sheet: behavior and environment. Washington, DC, American Geophysical Union, 257-281. (Antarctic Research Series 77.)

Wingham, D. J. 2000. Small fluctuations in the density and thickness of a dry firn column. f. Glaciol., 46(154), 399-411. 